UDC 616.24-002-053.2:614.1(477)

https://doi.org/10.26641/2307-0404.2020.4.221680

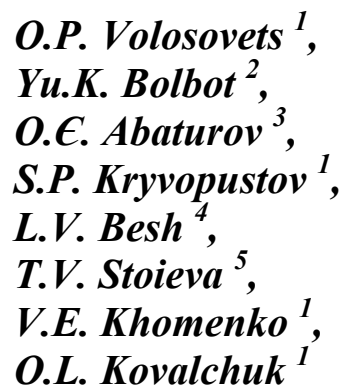

\title{
DYNAMICS OF THE INCIDENCE RATE OF PNEUMONIA IN CHILDREN IN UKRAINE OVER THE PAST 20 YEARS
}

Bogomolets National Medical University ${ }^{\text {I }}$

Department of Pediatrics $N 2$

Blvd. T. Shevchenko, 13, Kyiv, 01601, Ukraine

e-mail:volosovec@ukr.net

$S E$ «Dnipropetrovsk medical academy of Health Ministry of Ukraine»

Department of Pediatrics 3 and Neonatology ${ }^{2}$

e-mail: bolbot.u@gmail.com

Department of Pediatrcs 1 and Medical Genetics ${ }^{3}$

e-mail: alexabaturov56@gmail.com

V. Vernadsky str., 9, Dnipro, 49044, Ukraine

Danylo Halytsky Lviv National Medical University ${ }^{4}$

Department of Pediatrics $N 2$

Pekarska str., 69, Lviv, 79010, Ukraine

e-mail: lesya.besh@gmail.com

Odessa National Medical University ${ }^{5}$

Department of Pediatrics № 2

Valikhovsky Lane, 2, Odessa, 65082, Ukraine

e-mail:freesias@ukr.net

Начіональний медичний університет імені О.О. Богомольияя ${ }^{1}$

кафедра педіатрії № 2

(зав. - член-кор. НАМН України, д. мед. н., проф. О.П. Волосовець)

бульв. Т. Шевченка, 13, Київ, 01601, Украӥна

Д3 «Дніпропетровська медччна академія МОЗ Украӥни»

кафедра педіатрії 3 та неонатологї ${ }^{2}$

(зав. - д. мед. н., проф. Ю.К. Больбот)

кафедра педіатрії 1 та медичної генетики ${ }^{3}$

(зав. - д. мед. н., проф. О.С.Абатуров)

вул. В. Вернадського, 9, Дніпро, 49044, Украйна

Львівський національний медичний університет імені Данила Галиияького ${ }^{4}$

кафедра педіатрії № 2

(зав. - д. мед. н., проф. Л.В. Беш)

вул. Пекарська, 69, Львів, 79010, Украӥна

Одеський національний медичний університет ${ }^{5}$

кафедра педіатрії № 2

(зав. - д. мед. н., проф. Т.В. Стоєва)

Валіховський пров., 2, Одеса, 65082, Украйна

Цитування: Медичні перспективи. 2020. Т. 25, № 4. С. 174-181

Cited: Medicni perspektivi. 2020;25(4):174-181

Key words: children, morbidity, mortality, pneumonia

Ключові слова: діти, захворюваність, смертність, пневмонія

Ключевые слова: дети, заболеваемость, смертность, пневмония

Abstract. Dynamics of the incidence rate of pneumonia in children in Ukraine over the past 20 years. Volosovets O.P., Bolbot Yu.K., Abaturov O.E, Kryvopustov S.P., Besh L.V., Stoieva T.V., Khomenko V.E.,

Kovalchuk O.L. Pneumonia ranks third in the structure of hospital mortality in infants after perinatal pathology and congenital malformations in Ukraine. Over the past 20 years in Ukraine, there has been a 33,7\% increase in the 
incidence of pneumonia in children $(p<0.01)$, with the predominant detection of this pathology in children from regions of the country who have problematic issues in the proper provision of pediatric services. The highest incidence of pneumonia in all age groups was observed in children of Ivano-Frankivsk, Rivne, Kyiv and Vinnitsa regions. Thanks to the progressive development of domestic pediatrics and the introduction of modern medical and diagnostic technologies, in particular, vaccine prophylaxis, over the past 20 years, the death rate of children from acute infections of the upper respiratory tract, pneumonia and influenza has decreased by almost 5 times. Changes in recent years in the incidence of pneumonia in children correspond to the dynamics of the spread of influenza and acute respiratory viral infection, especially during the epidemics 2009-2010 and 2015-2016. Assessing the dynamics of this indicator in subsequent periods is extremely important in the context of the COVID-19 pandemic, which continues.

Реферат. Динамика показателя заболеваемости пневмонией детей Украины за последние 20 лет. Волосовець А.П., Больбот Ю.К., Абатуров А.Е., Кривопустов С.П., Беш Л.В., Стоева Т.В., Хоменко В.Е., Ковальчук О.Л. В Украине пневмония занимает третье место в структуре госпитальной летальности младенщев после перинатальной патологии и врожденных аномалий развития. За последние 20 лет в Украине наблюдается рост на 33,7\% заболеваемости детей пневмонией $(p<0,01)$ с преимущественным выявлением этой патологии у детей из областей страны, имеющих проблемные вопросы в надлежащем обеспечении педиатрической службы. Наибольший уровень заболеваемости пневмонией во всех возрастных группах наблюдался у детей Ивано-Франковской, Ровенской, Киевской и Винниикой областей. Благодаря прогрессивному развитию отечественной педиатрии и внедрению современных лечебно-диагностических технологий, в частности вакциинопрофилактики, за последние 20 лет смертность детей от острых инфекций верхних дыхательных путей, пневмонии и гриппа снизилась почти в 5 раз. Изменения за последние годы 6 заболеваемости детей пневмонией соответствуют динамике распространения гриппа и ОРВИ, особенно во время эпидемий 2009-2010 г2. и 2015-2016 г2. Оиченка в динамике этого показателя в последующие периоды крайне важна в контексте пандемии COVID-19, которая продолжается.

Pneumonia in children has been and remains an urgent medical and social problem for Ukraine and the world $[6,11]$. Respiratory diseases are one of the most common nosologies in children, constantly grow due to the virulence of the microflora and the unsatisfactory state of the environment, despite all modern achievements of clinical pediatrics in the field of antibiotic therapy and vaccine prophylaxis $[7,13]$.

In developed countries, the annual incidence of pneumonia is 3.3 per 1000 in children under 5 years and 1.45 per 1000 in children aged 0 to 16 years [6]. Recently, the situation has been exacerbated by the COVID-19 pandemic, which is known to be accompanied by bilateral pneumonia in both adults and children in severe cases [8].

According to the WHO, in 2017, pneumonia caused the death of more than 800,000 children under the age of 5 worldwide, accounting for up to $15 \%$ of all child mortality [11]. The mortality rate among hospitalized children under 5 years of age with pneumonia is less than $1 \%$, and in resourcepoor countries is several times higher $[9,12]$. In Ukraine, pneumonia in children in the structure of hospital infant mortality ranks third after perinatal pathology and congenital malformations [2].

The aim of this study was to determine the changes in the incidence of pneumonia in children of Ukraine over the past 20 years in age cohorts of children from different regions of Ukraine depending on the state of the environment.

\section{MATERIALS AND METHODS OF RESEARCH}

A study of changes in the incidence of pneumonia in children aged 0-17 years living in different regions of Ukraine was carried out. Methods of statistical assessment and epidemiological analysis of data of the Center for Medical Statistics of the Ministry of Health of Ukraine from 1993 to 2019 were used [3].

Volumes of pollutant emissions from stationary and mobile sources into the atmosphere in 2015 were established in accordance with the data of the annual statistical reference book of the collection of the State Statistics Service of Ukraine [10].

Statistical estimation methods were used, in particular the U-criterion of sign ranks (WilcoxonMann-Whitney test) to compare the incidence of pneumonia in children from the same regions of Ukraine at different times [5].

To establish a linear relationship, to determine the correlation and possible relationship between the volume of pollutant emissions into the atmosphere from stationary sources of pollution (hereinafter the volume of pollutant emissions) and the incidence of pneumonia in children from different regions, Spearman's rank correlation coefficient was used [5]. Statistical processing of the study results was performed using the software product STATISTICA 6.1 (StatSoftInc., Serial № AGAR909E415822FA) and Excel-2010. 


\section{RESULTS AND DISCUSSION}

According to the Center for Medical Statistics of the Ministry of Health of Ukraine, the incidence of pneumonia in children aged 0-17 years in 2017 was 62,470 new cases, or 8.2 per 1 thousand of population. For comparison, in 199676598 cases of pneumonia were detected for the first time, or 6.13 per 1,000 children.

As can be seen from Table 1, over the past 20 years, the incidence of pneumonia in children of the country has probably increased by $33.7 \%(\mathrm{p}<0.01)$, as the U-criterion of Mann-Whitney rank has reached a correspondingly critical value -178 which is in the zone of significance at a certain number of comparable groups of indicators. These data are in line with the global trend of pneumonia growth in the world, especially in countries with low per capita incomes and health care systems with limited resources [8].

Dynamics of change in the incidence of pneumonia (ICD - J12-J16, J18) i n children of Ukraine (0-17 years) from 1996 to 2017 according to the Center for Medical Statistics of the Ministry of Health of Ukraine

\begin{tabular}{|c|c|c|c|c|c|}
\hline \multirow[t]{2}{*}{ Regions of the country } & \multicolumn{2}{|c|}{$\begin{array}{l}\text { Incidence of pneumonia } \\
\text { in children in } 1996\end{array}$} & \multicolumn{2}{|c|}{$\begin{array}{c}\text { Incidence of pneumonia } \\
\text { in children } \\
\text { in } 2017\end{array}$} & \multirow{2}{*}{$\begin{array}{c}\text { Dynamics } \\
\text { of changes } \\
\text { in comparison } \\
\text { with } 1996\end{array}$} \\
\hline & absolute numbers & per 1000 children & absolute numbers & per 1000 children & \\
\hline Ukraine & 76598 & 6.13 & 62470 & 8.20 & $+33.7 \%$ \\
\hline Vinnytsia & 2780 & 6.41 & 3338 & 11.48 & $+79.1 \%$ \\
\hline Volyn & 2552 & 8.07 & 2098 & 8.77 & $+8.7 \%$ \\
\hline Dnepropetrovsk & 3261 & 6.96 & 3084 & 5.36 & $-23.1 \%$ \\
\hline Donetsk & 4727 & 4.64 & 3218 & 10.48 & $+125.8 \%$ \\
\hline Zhytomyr & 1871 & 5.30 & 2224 & 9.20 & $+73.5 \%$ \\
\hline Transcarpathian & 3299 & 9.23 & 2317 & 7.93 & $-14.1 \%$ \\
\hline Zaporizhzhia & 2224 & 4.14 & 2189 & 7.44 & $+79.7 \%$ \\
\hline Ivano-Frankivsk & 6446 & 17.80 & 4868 & 17.46 & $-0.07 \%$ \\
\hline Kyiv & 6640 & 18.47 & 4426 & 13.47 & $+72.9 \%$ \\
\hline Kirovohrad & 1435 & 4.70 & 1535 & 9.00 & +91.5 \\
\hline Luhansk & 1379 & 2.12 & 1206 & 11.12 & $+424.5 \%$ \\
\hline Lviv & 6450 & 10.72 & 2458 & 5.07 & $-52.7 \%$ \\
\hline Mykolayiv & 1784 & 4.71 & 1411 & 6.77 & $+43.7 \%$ \\
\hline Odessa & 3316 & 4.91 & 4256 & 9.27 & $+88.8 \%$ \\
\hline Poltava & 3629 & 10.07 & 2375 & 10.12 & $+0.05 \%$ \\
\hline Rivne & 2708 & 8.19 & 4035 & 14.50 & $+77.05 \%$ \\
\hline Sumy & 936 & 2.57 & 1780 & 10.27 & $+299.2 \%$ \\
\hline Ternopil & 2323 & 8.6 & 2377 & 11.92 & $+38.6 \%$ \\
\hline Kharkiv & 3101 & 4.26 & 3841 & 9.01 & $+111.5 \%$ \\
\hline Kherson & 2049 & 6.45 & 2181 & 11.02 & $+70.8 \%$ \\
\hline Khmelnytsky & 1401 & 3.27 & 1552 & 6.51 & $+99.1 \%$ \\
\hline Cherkasy & 2200 & 4.49 & 1019 & 5.02 & $+11.8 \%+$ \\
\hline Chernivtsi & 753 & 2.02 & 889 & 4.82 & $+138.6 \%$ \\
\hline Chernihiv & 3605 & 13.9 & 1714 & 10.42 & $-25.1 \%$ \\
\hline City of Kyiv & 3155 & 4.17 & 2079 & 3.96 & $-4.04 \%$ \\
\hline
\end{tabular}

Note. * Data on the Autonomous Republic of Crimea and the city of Sevastopol are not included due to their absence. 
The highest incidence of pneumonia is observed among the age group of children 0-6 years $-34,117$ cases $(10.8$ per 1,000 population and $54.5 \%$ of the total number of cases), then among children aged 714 years - 22449 cases (6.69 per 1000 and 35.9\%) and $15-17$ years -5904 (5.47 per 1000 and $9.45 \%$ ). It should be noted that the incidence of pneumonia in young children in Ukraine was three times higher than in developed countries.

The age distribution of children with pneumonia in 1996 was somewhat different. Early childhood children also dominated $-55.2 \%$ of diagnosed pneumonia, schoolchildren $-38.3 \%$ and adolescents $6.4 \%$. That is, over 20 years, pneumonia began to be detected 1.5 times more often in children aged 1517 years with a corresponding decrease in its detection in young children and schoolchildren.
The highest incidence of pneumonia in all three age groups was observed in children of IvanoFrankivsk, Rivne, Kyiv and Vinnytsia regions. It should be noted that all four region, according to the current legislation, are referred to regions with radiological control territories, which were formed as a result of the Chernobyl accident in 1986. There were also high rates of pneumonia in children aged 0-6 years from Donetsk and Luhansk regions and schoolchildren of Ternopil region. In 1996, the highest incidence of pneumonia in children was in Kyiv, Ivano-Frankivsk, Chernihiv and Lviv regions.

The lowest incidence of pneumonia in children of all age cohorts was in the city of Kyiv, Chernivtsi, Cherkasy and Lviv regions (Table 2).

Table 2

\section{Distribution of regions of Ukraine by levels of pneumonia in children}

\begin{tabular}{|c|c|}
\hline The incidence of pneumonia in children & Regions of the country \\
\hline Very high incidence of pneumonia in children & $\begin{array}{l}\text { Ivano-Frankivsk } \\
\text { Rivne } \\
\text { Kyiv }\end{array}$ \\
\hline $\begin{array}{l}\text { The incidence of pneumonia in children is higher than the national } \\
\text { average }\end{array}$ & $\begin{array}{l}\text { Ternopil } \\
\text { Vinnytsia } \\
\text { Kherson } \\
\text { Donetsk } \\
\text { Luhansk } \\
\text { Chernihiv } \\
\text { Poltava } \\
\text { Sumy }\end{array}$ \\
\hline $\begin{array}{l}\text { The incidence of pneumonia in children is close to the national } \\
\text { average }\end{array}$ & $\begin{array}{l}\text { Odessa } \\
\text { Kharkiv } \\
\text { Zhytomyr } \\
\text { Transcarpathian } \\
\text { Luhansk } \\
\text { Zaporizhzhia } \\
\text { Kirovohrad } \\
\text { Mykolayiv } \\
\text { Khmelnytsky }\end{array}$ \\
\hline Low incidence of pneumonia in children & $\begin{array}{l}\text { Lviv } \\
\text { Dnepropetrovsk } \\
\text { Cherkasy } \\
\text { Chernivtsi } \\
\text { City of Kyiv }\end{array}$ \\
\hline
\end{tabular}

The specific weight of pneumonia among all newly registered diseases of the pediatric population in Ukraine today is only $0.64 \%$ (in $1996-0.76 \%$ ), but this can not diminish the importance of this dangerous disease, especially for infants and young children.

Thus, respiratory diseases now account for $58.14 \%$ of all infant diseases (in $1996-45.4 \%$ ).
Among respiratory diseases, acute infections of the upper respiratory tract, pneumonia and influenza in 2019 accounted for $96.3 \%$ of all respiratory diseases, or in numerical terms 232,715 cases -779.9 per 1,000 population (in $1996-779.6$ per 1000 ). As a result of these pathological conditions in 2019, 69 children died in the first year of life, including 31 
children in hospital ( 0.23 per 1,000 population). This is $9.79 \%$ of all registered causes of infant mortality last year. The highest incidence of pneumonia in infants was observed in Zhytomyr, Zaporizhzhia, Ivano-Frankivsk regions and Kyiv. The lowest incidence of pneumonia in children of the first year of agee was in Ternopil, Volyn and Kharkiv regions.
Due to the progressive development of domestic pediatrics and the introduction of modern medical and diagnostic technologies, including vaccination, over the past 20 years, infant mortality from acute upper respiratory tract infections, pneumonia and influenza has been reduced almost by 5 times (Fig. 1).

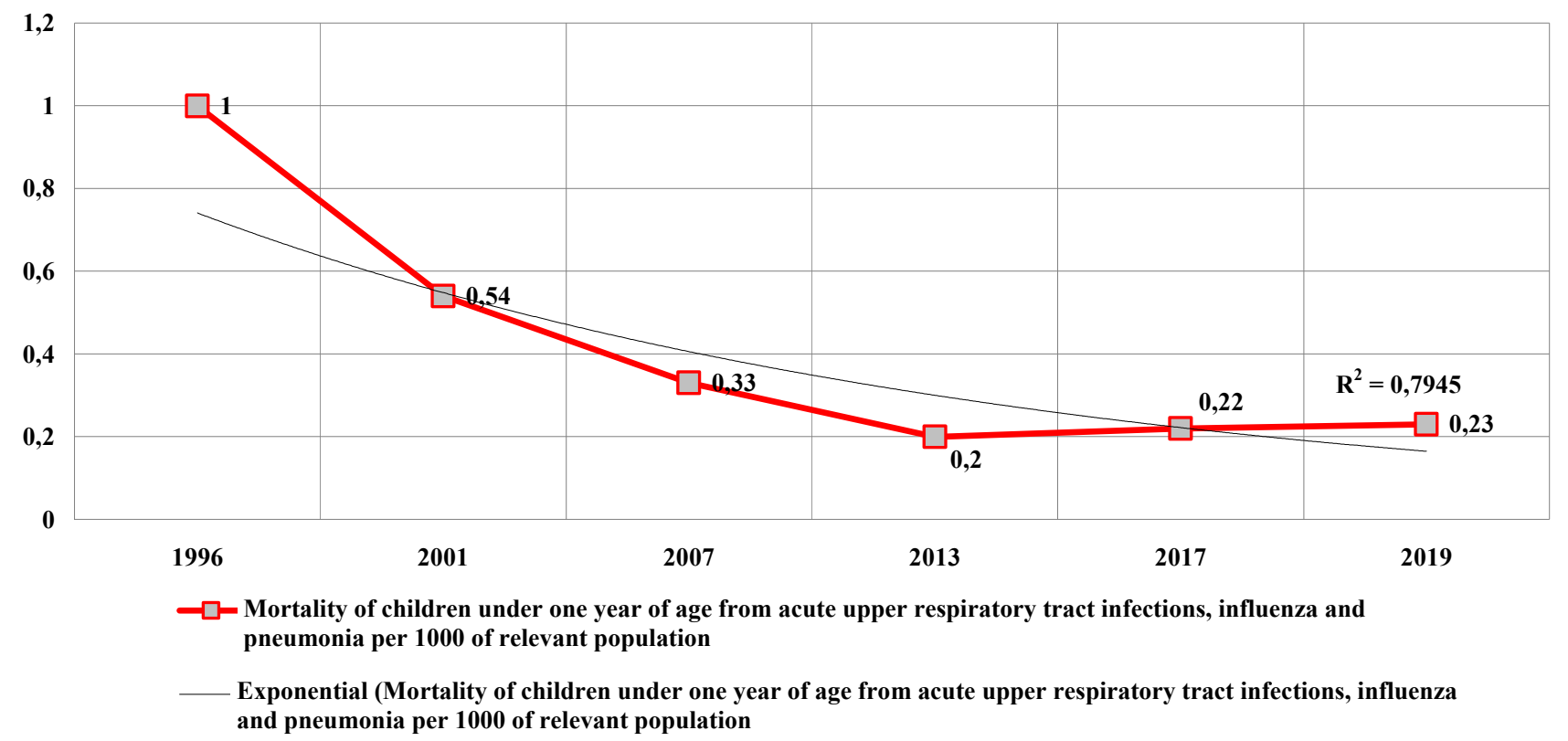

Fig. 1. Dynamics of mortality of children under one year of age from acute upper respiratory tract infections, influenza and pneumonia from 1996 to 2019 and the trend of its exponential decrease (per 1000 of relevant population)

Among children of Kherson, Sumy, Vinnytsia, Zhytomyr, Kirovohrad regions in 2019 there were no fatalities caused by acute upper respiratory tract infections, influenza and pneumonia. Particular attention should be paid to the Transcarpathian, Donetsk and Odessa regions, where the highest mortality rates of children under 1 year of age from acute respiratory infections, pneumonia and influenza is $1.08,0.48$ and 0.46 , respectively, per 1,000 of the relevant contingent with a national rate of 0.23 per 1,000 children. 20 years ago, high mortality from these conditions was in IvanoFrankivsk, Donetsk and Transcarpathian regions.

As can be seen from Figure 2, the first wave of pneumonia incidence increased by $52.2 \%$ from 1996 to 2001 , then the incidence of pneumonia began to decline, reaching relative minimum in 2003 (7.25 per 1,000 children). .

The increase in the incidence of pneumonia in 2005-2006 took place against the background of another epidemic outbreak of measles. The maximum incidence of pneumonia in children was observed in 2009-2010 (10.89 per 1000 children), which coincides in time with the epidemic of pandemic "swine" flu in Ukraine, one of the main clinical variants of which was viral pneumonia in adults and children [1].

A similar increase in the incidence of pneumonia in children was also observed in 2015-2016, which could also be associated with an increase in the incidence of influenza and SARS in children during this period [4]. The rise in pneumonia incidence in 2014-2016 could also be linked to the fighting in the east of the country and the large number of internal refugees from the war zones, including more than 200,000 children left homeless and in need of medical care due to the war. This can be evidenced by the high level of pneumonia in children from Donetsk and Luhansk regions, which was not observed 20 years ago.

In general, since 2011 there has been a wave-like trend to reduce the incidence of pneumonia to 8.32 per 1000 children in 2017 - the last year of statistical analysis of the incidence of children 
aged 0-17 years, which was conducted by the Ministry of Health of Ukraine.

correspond to the relative decrease in the overall morbidity of children in Ukraine, which in recent

It should be noted that over 20 years the growing pneumonia incidence in children did not fully

years has stabilized at the level of 1291.7 per 1000 of children [7].

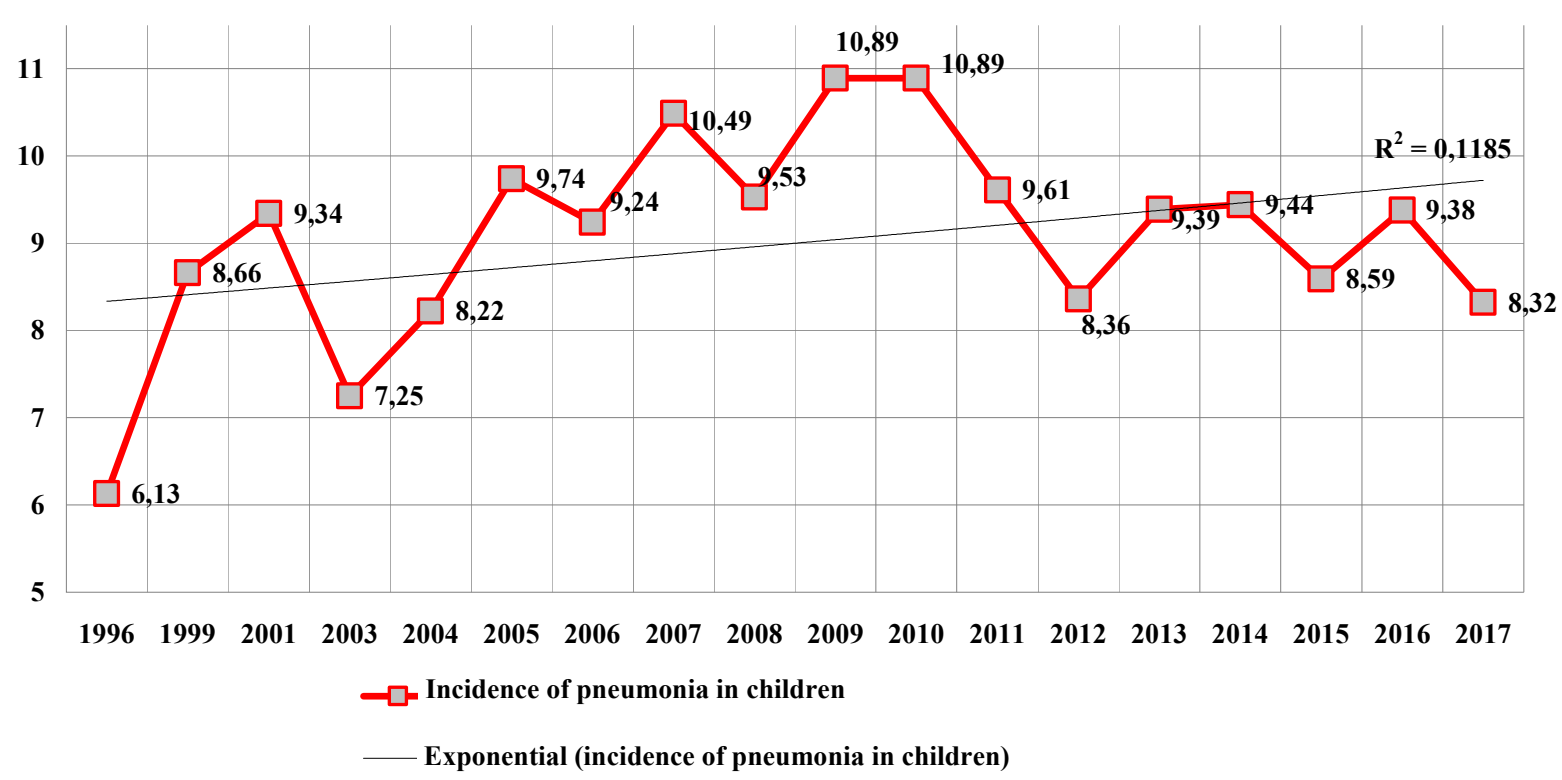

Fig. 2. Dynamics of pneumonia incidence in children of Ukraine in 1996-2017 and the trend of its exponential growth (per 1000 children)

Given the role of environmental ecology and housing in the possible development of pneumonia in children, we conducted an appropriate correlationregression analysis between the incidence of pneumonia in children and the amount of pollutant emissions from stationary and mobile sources into the atmosphere in 2015 per capita. The established critical value of the Spearman correlation coefficient $(\rho)$ reached the level of only 0.038 , which testified to the absence of a relationship between these features $(p>0.05)$. It is of interest, in general as for respiratory diseases in children, we proved the direct effect of moderate force $\left(r_{s}=0.578\right)$ of the relationship between pollutant emissions from stationary and mobile sources into the atmosphere per person and the incidence of pneumonia in children.

Revealed increased incidence of pneumonia in children over the past 20 years has been due to a set of factors and, above all, in our opinion, due to advanced training of pediatricians and family physicians, improved diagnosis and application of modern guidelines and methodological approaches to diagnosis.

Of course, to analyze the possible increase in the incidence of pneumonia in adults and children against the background of the COVID-19 pandemic in 2020, it is necessary to restore a comprehensive statistical assessment of the health of children in the country.

\section{CONCLUSIONS}

Over the last 20 years, in Ukraine there is an increase by $33.7 \%$ in the incidence of pneumonia with the predominant detection of this pathology in children from regions of the country in which there are problems in the proper provision of pediatric services. Changes in recent years in the incidence of pneumonia in children correspond to the dynamics of the spread of influenza and SARS, especially during the epidemics of 2009-2010 and 2015-2016. Tracking this indicator in the dynamics in subsequent periods is extremely important in the context of the COVID-19 pandemic that continues.

Conflict of interest. The authors declare no conflict of interest.

Financing from the state budget. Implementation of research work of the Department of Pediatrics N2 "Diagnosis of disorders of the cardiovascular, respiratory and 
digestive systems in newborns and children with advanced non-infectious pathology and their therapy" (2012-2016) of O.O. Bogomolets Na- tional Medical University. State registration code $0112 U 001772$.

\section{REFERENCES}

1. Volosovets OP, Vasylyeva NA, Dnistryan SS, et al. [Epidemy of flu in 2009 in western region of Ukraine: age aspects, etiologic structure. Infection disease]. 2009;4:28-33. Ukainian.

DOI: https://doi.org/10.11603/1681-2727.2009.4.828.

2. Maidannyk VG, Yemchynska EA. [Clinical guidelines for the diagnosis and treatment of communityacquired pneumonia in children from the standpoint of evidence-based medicine]. Kyiv; 2014;43. Ukrainian.

3. [Providing medical care to children aged $0-17$ in health care facilities under the management of the Ministry of Health of Ukraine: statistical and analytical guide 1996-2019]. editor, VM Zabolot'ko. [Internet]; 2020. Ukrainian. Available from:

https://www.ukrmedstat@medstat.gov.ua

4. Kramariov SO, Yevtushenko VV, Vygovska OV, et al. [Features of influenza seaason 2016 in children]. Aktualna Infektologiia. 2016;1(10):209-12. Ukrainian. doi: https://doi.org/10.22141/2312-413x.1.10.2016.74550

5. Editor, Fulekar MH. Bioinformatics: Applications in Life and Environmental Sciences. Springer. 2009;110. doi: https://doi.org/10.1007/978-1-4020-8880-3

6. Harris M, Clark J, Coote N, et al. British Thoracic Society guidelines for the management of community acquired pneumonia in children: update 2011. Thorax 2011;66(Suppl 2).

doi: https://doi.org/10.1136/thoraxjnl-2011-200598

7. Volosovets OP, Kryvopustov SP, Volosovets TM, Abaturov OE, Kryuchko TO. Changes in health status of child population of Ukraine after Chernobyl catastrophe.
Wiadomości Lekarskie 2019;LXXII(10):1974-6. doi: https://doi.org/10.36740/WLek201910123

8. Götzinger F, Santiago-García B, NogueraJulián A, Lanaspa M, et al. COVID-19 in children and adolescents in Europe: a multinational, multicentre cohort study. [Internet]. Published: 2020. 25 June. doi: https://doi.org/10.1016/S2352-4642(20)30177-2

9. Griffin MR, Mitchel E, Moore MR, et al. Declines in pneumonia hospitalizations of children aged $<2$ years associated with the use of pneumococcal conjugate vaccines - Tennessee, 1998-2012. MMWR Morb Mortal Wkly Rep. 2014;63:995. PMC4860731.

10. Environment of Ukraine. Statistical yearbook. State Statistics Service of Ukraine. Kyiv; 2018. p. 225.

11. Kassebaum N, Kyu HH, et al. Global Burden of Disease Child and Adolescent Health Collaboration, Child and Adolescent Health From 1990 to 2015: Findings From the Global Burden of Diseases, Injuries, and Risk Factors 2015 Study. JAMA Pediatr. 2017;171:573. doi: https://doi.org/10.1001/jamapediatrics.2017.0250

12. McAllister DA, Liu L, Shi T, et al. Global, regional, and national estimates of pneumonia morbidity and mortality in children younger than 5 years between 2000 and 2015: a systematic analysis. Lancet Glob Health. 2019;7:e47. doi: https://doi.org/10.1016/S2214109X(18)30408-X

13. Matthew S. Kelly and Thomas J. Sandora Chapter 428 Community-Acquired Pneumonia in Kliegman, R. Nelson textbook of pediatrics, Edition 21. Philadelphia, PA: Elsevier; 2020;2266-74.

\section{СПИСОК ЛІТЕРАТУРИ}

1. Епідемія грипу 2009 р. у західному регіоні України: вікові аспекти, етіологічна структура / О. П. Волосовець та ін. Інфекиіийні хвороби. 2009. № 4. C. 28-33.

DOI: https://doi.org/10.11603/1681-2727.2009.4.828.

2. Майданник В. Г., Ємчинська Є. О. Клінічні настанови 3 діагностики та лікування позалікарняної пневмонії у дітей $з$ позиції доказової медицини. Київ, 2014. 43 c.

3. Надання медичної допомоги дітям 0-17 років у закладах охорони здоров'я, що перебувають у сфері управління МO3 України: статистично-аналітичний довідник 1996-2019 / гол. ред. В. М. Заболотько. 2020. URL: https://www.ukrmedstat@medstat.gov.ua.

4. Особливості грипу сезону 2016 року в дітей / С. О.Крамарьов та ін. Актуальная инфектология. 2016. № 1. C. 108-112.

DOI: https://doi.org/10.22141/2312-

413x.1.10.2016.74550
5. Bioinformatics: Applications in Life and Environmental Sciences / Ed. M. H. Fulekar. Springer, 2009. 110 p. DOI: https://doi.org/10.1007/978-1-4020-8880-3

6. British Thoracic Society guidelines for the management of community acquired pneumonia in children: update 2011 / M. Harris et al. Thorax. 2011. Vol. 66. Suppl. 2. DOI: https://doi.org/10.1136/thoraxjnl-2011200598

7. Changes in health status of child population of Ukraine after Chernobyl catastrophe / O. P. Volosovets et al. Wiadomości Lekarskie. 2019. Vol. LXXII, No. 10. P. 1974-1976.

DOI: https://doi.org/10.36740/WLek201910123

8. COVID-19 in children and adolescents in Europe: a multinational, multicentre cohort study / F. Götzinger et al. 2020. 25 June.

DOI: https://doi.org/10.1016/S2352-4642(20)30177-2

9. Declines in pneumonia hospitalizations of children aged $<2$ years associated with the use of pneumo- 
coccal conjugate vaccines - Tennessee, 1998-2012 / M.R. Griffin et al. MMWR Morb Mortal Wkly Rep. 2014. Vol. 63. P. 995. PMC 4860731.6

10. Environment of Ukraine: statistical yearbook. State Statistics Service of Ukraine. Kyiv, 2018. 225 p.

11. Global Burden of Disease Child and Adolescent Health Collaboration, Child and Adolescent Health From 1990 to 2015: Findings From the Global Burden of Diseases, Injuries, and Risk Factors 2015 Study / N. Kassebaum et al. JAMA Pediatr. 2017. Vol. 171. P. 573. DOI: https://doi.org/10.1001/jamapediatrics.2017.0250
12. Global, regional, and national estimates of pneumonia morbidity and mortality in children younger than 5 years between 2000 and 2015: a systematic analysis / D. A. McAllister et al. Lancet Glob Health. 2019. Vol. 7.P. e47.

DOI: https://doi.org/10.1016/S2214-109X(18)30408-X

13. Matthew S. Kelly and Thomas J. Sandora Chapter 428 Community-Acquired Pneumonia in Kliegman, R. Nelson textbook of pediatrics (Edition 21). Philadelphia, PA: Elsevier, 2020. P. 2266-2274.

The article was received 2020.09.09 